\title{
TELOMERE LENGTH AS A MOLECULAR BIOMARKER FOR HUMAN AGE PREDICTION: A QUANTITATIVE REAL-TIME PCR STUDY AMONG SAMPLE OF EGYPTIANS
}

\author{
$B \mathcal{Y}$ \\ Abdelmonem G. Madboly; Naglaa F. Alhusseini* and Abeer A. Abo Elazm** \\ Departments of Forensic Medicine \& Clinical Toxicology, Medical Biochemistry, ${ }^{*}$ Medical Microbiology ${ }^{* *}$ \\ \& Immunology, Faculty of Medicine, Benha University
}

\begin{abstract}
The fact that telomere shortening occurs with aging leads to the hypothesis that a correlation could be made between telomere length (TL) and suspect age. This study aimed to assess if $T L$ can be used as an investigational tool to predict human age through developing a formula based on this correlation with accuracy suitable to be applied in forensic practice. A quantitative real-time PCR study was carried out on 80 Egyptians, ranging in age from 1- 79 years. The results confirmed that the relative TL significantly shortened with aging; " $r$ " $=-0.903$ ( $p<$ 0.001). The human age could be determined by the following formula: $(Y=66.9-28 X)$, (Y: age in years; $X$ : relative $T L)$, with a regression analysis between relative $T L$ and age had an $R^{2}=$ 0.815 . The standard error of age estimate was \pm 10.14 years. The present study concluded that estimation of human age based on the relative TL measured by quantitative real-time PCR may be a useful method for age prediction, especially when there is no morphologic information in the biological samples, but the estimated standard error of age prediction in this study was quite high ( \pm 10 years) to be used with certainty in forensic investigations. Inter-individual variations in TL and variability among the gender must be also considered when applying this method. So, this method could only give a rough estimation of age and it may be a complementary method for age estimation from soft tissues.
\end{abstract}

Keywords: Telomere length, molecular, biomarker, human age prediction, quantitative real-time PCR, Egyptians.

\section{INTRODUCTION}

In forensic practice, scientists compare unique genetic DNA profiles of individuals extracted from biological evidences found at crime scene with the DNA profile of suspects or with all profiles in a state or national databank (Kelly et al., 2013).

When there is no suspect to compare 
with, the scientist cannot help the investigators regarding what physical characteristics to look for in a suspect by using DNA profile, other than gender (Ballantyne, 2007).

It would be useful for the scientists to predict the outward appearance of an individual such as age, height, ethnicity, hair and skin color, by analyzing the DNA left behind in a crime scene to narrow down the range of suspects (Hewakapuge et al., 2008).

One important phenotypic characteristic is age of the suspect. Medical examiners have been able to determine the age of an individual by examining dental records and various features and measurements of the skeleton (Lynnerup et al., 2010).

A sample of biological evidence (e.g. a bloodstain) usually carries no morphological information. In this case, age estimation method on a molecular basis would be very useful (Karlsson et al., 2008).

There are four basic methods for estimation of the age of a person at the molecular level; deletions of mitochondrial DNA, shortening of telomeres, racemization of aspartic acid and advanced glycation end products (AGEs) (Meissner and Ritz-Timme, 2010).

Telomeres (from the Greek telos [end] and meros [part]) are DNA protein complexes at the ends of chromosomes, composed of tandem TTAGGG repeats ranging from few to 15 kilo bases in length. Telomeres play an essential role in the maintenance of genomic stability by protecting the ends of chromosomes from DNA damage (Thomas et al., 2008; Price et al., 2013).

Very little is known about the quantitative relationship between human telomere length (TL) and donor age. As a result, it is difficult to determine age by existing data. In addition, there is no research report of systemic population about telomere shortening (Takasaki et al., 2003; Ren et al., 2009).

Saeed et al. (2012) confirmed that it is necessary to design basic science experiments for better evaluation of the role of TL in molecular prediction of biological age, as it remains the most promising biomarker for this purpose.

As forensic biological samples may contain highly fragmented DNA molecules, analyzing telomere repeats using real-time polymerase chain reaction (PCR) enables analysis of DNA of low concentration and partially degraded (Karlsson et al., 2008; Alaeddini et al., 2010).

Therefore, this study was conducted to assess the correlation between TL meas- 
ured by a quantitative real-time PCR and human age, to see if TL can be used as an investigational tool for predicting human age through developing a formula (an equation) based on this correlation, with accuracy suitable to be applied in forensic practice.

\section{SUBJECTS AND METHODS}

\section{Subjects :}

This is a quantitative real-time PCR study that was carried out on randomly selected 80 subjects, ranging in age from 179 years, with the following inclusion criteria:

- All are Egyptians.

- Healthy with no history of any chronic diseases or tumors.

- Unrelated (to exclude the effects of ethnicity and inheritance effects on telomere length).

Active smokers, obese or individuals on any kind of chronic medical treatment were excluded from the study (to exclude their effects on telomere length).

The subjects included in this study were stratified into a balanced sex distributed eight groups (each group had an equal numbers of males and females of corresponding ages), and each group comprised a 10-years, representing each decade of life; $\{(\leq 10$ years), (11-20 years), (2130 years), (31-40 years), (41-50 years), (51-
60 years), (61-70 years) and (71-80 years)\}. Informed consent was taken from all subjects included in the study (from adults or from caretakers of minors); all subjects completed an in-person interview that ascertained information about the aim, general steps and scientific value of this study.

This study was approved by The Local Research Ethical Board of Faculty of Medicine, Benha University. All results were registered in special sheets of the study, which were confidential.

\section{Sampling :}

Whole peripheral venous blood sample (about $3 \mathrm{ml}$ ) was collected from each subject enrolled in the study, by trained nursing staff of Benha University Hospitals, and put immediately in vacationer tubes containing EDTA.

Each sample was mixed and divided into two eppendorf tubes, stored at $-80^{\circ} \mathrm{C}$ for further processing at the laboratory.

\section{Genomic DNA extraction :}

DNA was extracted using QIAamp DNA blood mini kit (Qiagen, Germany), following the manufacturer instructions.

The extracted DNA concentration was confirmed through measurement by NanoDrop 2000c Spectrophotometer. Readings were taken at wave lengths of 260 and 280 
nm. Concentration of DNA sample was measured $=50 \mathrm{ug} / \mathrm{mL}^{-1 *} \mathrm{~A} 260 *$ (Alhusseini et al., 2014).

\section{Quantitative Real time PCR :}

The reference DNA sample was prepared from pooled sample. Four serial dilutions were prepared and used in amplification plates as standards.

In ABI7900 fast real time machine (Applied Biosystem USA), the design of the plates was to measure telomer hexamer repeat (THR) copy number in each individual sample and reference DNA diluted sample in the same plate in a condition: $95^{\circ} \mathrm{C}, 15 \mathrm{~min}$ for initial denaturation followed by 20 cycle of $95^{\circ} \mathrm{C}, 30$ sec.; $54^{\circ} \mathrm{C}$, $1 \mathrm{~min}$.; $72^{\circ} \mathrm{C}$, 30sec.

The same design of the previous plate was done in another plate for both single copy gene (SCG) 36B4 and housekeeping gene human $\beta$-globin (HBG) with conditions $95^{\circ} \mathrm{C}, 15 \mathrm{~min}$ for initial denaturation followed by 30 cycle of $95^{\circ} \mathrm{C}, 30 \mathrm{sec}$; $58^{\circ} \mathrm{C}$ , $1 \mathrm{~min}$.; $72^{\circ} \mathrm{C}, 30$ sec. The primers used in these amplifications are described in table
(1). The master mix used in amplification was SuperReal PreMix Plus (SYBR Green) TIANGENE BIOTECH.

The autosomal single copy gene 36B4 gene, which encodes acidic ribosomal phosphoprotein $\mathrm{PO}$, is located on chromosome No. 12 and we chose the 36B4 gene, because it has already been validated for gene dosage studies (Boulay et al., 1999).

There is no reliable method to directly measure telomere length (TL) in human cells (Ren et al., 2009). Measurement of relative TL depends on quntitation of THR copy number normalized to autosomal SCG copy number (Cawthon, 2002). The ratio between THR/SCG is proportional to the TL if the number of copies of SCG Cell $^{-1}$ is the same in all individuals being studied.

We must be sure that the number of cells were equall in each sample used, thereby we normalized the SCG quantity ( $C_{t}$ versus Log flouresence) to housekeeping gene quantity $\beta$-globin, $\Delta C_{t}$ SCG $/ \Delta$ $C_{t}{ }^{\beta}$-globin for all samples. It should be

Table (1) : The primers used in reference DNA amplifications (Alhusseini et al., 2014).

\begin{tabular}{|l|l|l|}
\hline \multirow{2}{*}{ Gene } & \multicolumn{1}{|c|}{ Forward } & \multicolumn{1}{|c|}{$\left(\mathbf{5}^{\prime}-\mathbf{3}^{\prime}\right)$} \\
\cline { 2 - 3 } THR & $\begin{array}{l}\text { GGTTTTTGAGGGTGAGGGTGAGGGTG } \\
\text { AGGGTGAGGGT }\end{array}$ & $\begin{array}{l}\text { TCCCGACTATCCCTATCCCTATCCCTAT } \\
\text { CCCTATCC-CTA }\end{array}$ \\
\hline $36 B 4$ & CAGCAAGTGGGAAGGTGTAATCC & CCCATTCTATCATCAACGGGTACAA \\
\hline HBG & GCTTCTGACACAACTGTGTTCACTAGC & CACCAACTTCATCCACGTTCACC \\
\hline
\end{tabular}


$1 \pm 0.05$. Since the TL was quantified as a ratio, the absolute TL in base pairs was not obtained. The relative TL was believed to reflect the actual differences in TL in individuals (Nakagawa et al., 2004).

\section{Statistical design:}

The collected data were organized, tabulated and analyzed using SPSS version 16 software (Spss Inc, ILL Company, USA). Data were expressed as mean and standard deviation. Kolomogrov Smirnov test was used to assess the distribution of TL in different age groups, it was normally distributed ( $P>0.05$ in all age groups). Person's correlation coefficient (r), Student " $\mathrm{t}$ " and ANOVA were used as tests of significance. Simple linear regression analysis was used to determine an equation to predict the age from the value of TL. The accepted level of significance in this work was at $\mathrm{P}<0.05$ (Dawson and Trapp, 1994).

\section{RESULTS}

In the present study the relative telomere lengths of 80 Egyptian individuals aged from 1-79 years old were measured using a quantitative real-time PCR method.

\section{Correlation between relative telomere} length (TL) and age of the individuals included in the study :

The present work clearly illustrated that the relative TL of all individuals in- cluded in the study significantly shortened with aging, the correlation coefficient " $r$ " $=-0.903(\mathrm{p}<0.001)$, as shown in Fig. (1).

When the total sample was divided into eight age groups representing the decades of life, the results of the present study showed highly significant $(\mathrm{p}<0.001)$ decrease in mean relative TL among the different age groups (Figure 2).

Correlation between the relative TL and age of the individuals included in the study, according to the gender distribution:

In the present study there was a gender-specific difference in relative TL; it was significantly $(p<0.001)$ longer in females than males of the corresponding age among all studied individuals. When the studied individuals were classified into eight age groups representing the decades of life, the mean relative TL was significantly $(\mathrm{p}<0.05)$ longer in females than males, except in age groups $(<10$ years, 31-40 years and 41-50 years) which was insignificantly $(p>0.05)$ longer in females than males (Figures 3 and 4).

Regression analysis for prediction of age from the relative TL \& the formula (equation) for age prediction :

A regression analysis was done and the relationship between relative TL and age had an $R^{2}$ value of 0.815 for the total indi- 
viduals; 0.796 for males, and 0.839 for females. The present study developed a formula (equation) to calculate the age of each individual enrolled in the study from the relative TL $(\mathrm{Y}=66.9-28 \mathrm{X})$, and another two separate equations for males and females $(Y=65.3-27.05 X$ and $Y=68.8-29.1$ respectively), ( $\mathrm{Y}$ : age in years; $\mathrm{X}$ : relative $\mathrm{TL})$. To evaluate the accuracy of this equa- tion; the actual ages of the subjects were compared with estimated ages using the mean prediction error (ME), which was 9.92 years for the total individuals, 10.2 years for males, and 9.01 years for females. The standard error of estimate was \pm 10.14 years for the total individuals, \pm 10.81 years for males, \pm 9.59 years for females, as illustrated in table (2).

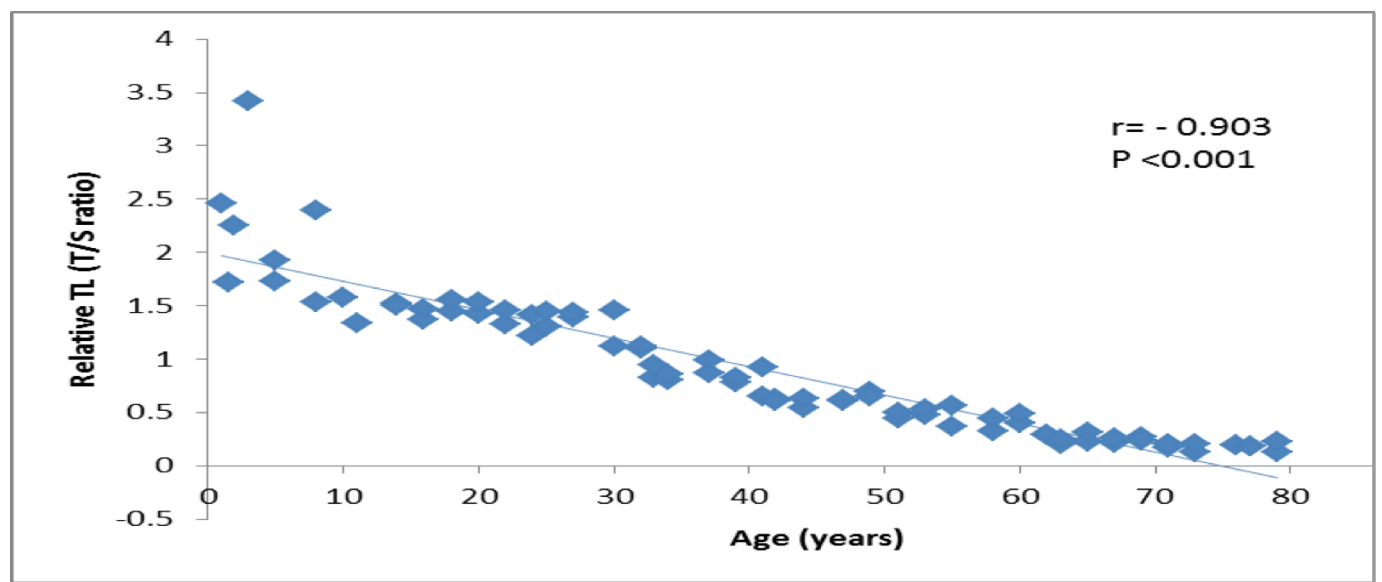

Fig. (1) : Scatter plot showing the correlation between relative telomere length (TL) and age in all individuals included in the study $(\mathrm{n}=80)$, aged from $1-79$ years old, $(\mathrm{r}=-0.903)$ and $\mathrm{p}(<0.001)$.

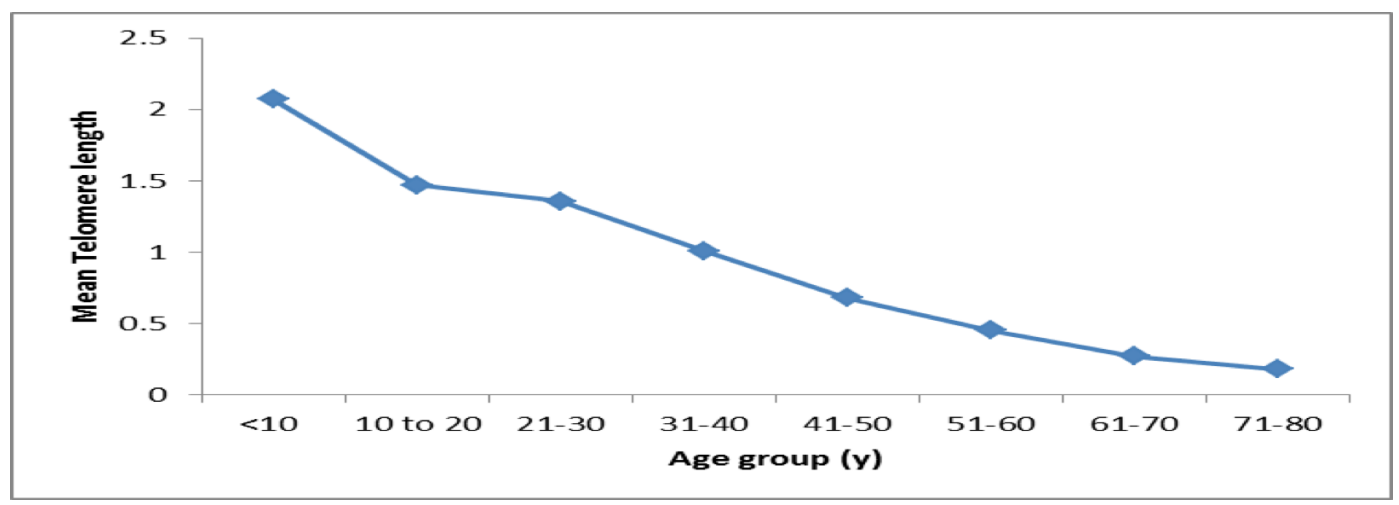

Fig. (2) : Scatter plot showing the mean relative telomere length (TL) in relation to the age of individuals in different eight age groups (each group comprised 10-years, representing each decade of life). Results showed significant decrease of mean relative TL among the eight subgroups, $\mathrm{p}<0.001$. 


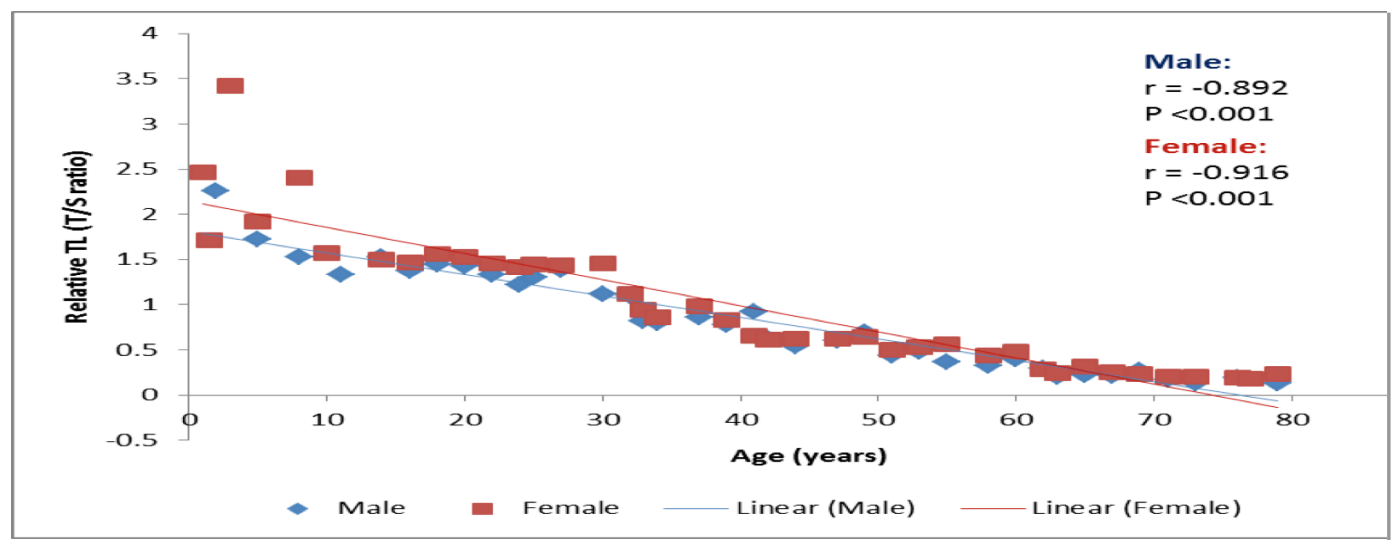

Fig. (3) : Scatter plot showing the correlation between relative telomere length (TL) and age of all individuals included in the study, according to gender distribution; among males $(n=40, r=-0.892)$ and females $(n=40, r=-0.916)$, and $p<0.001$ for both males \& females.

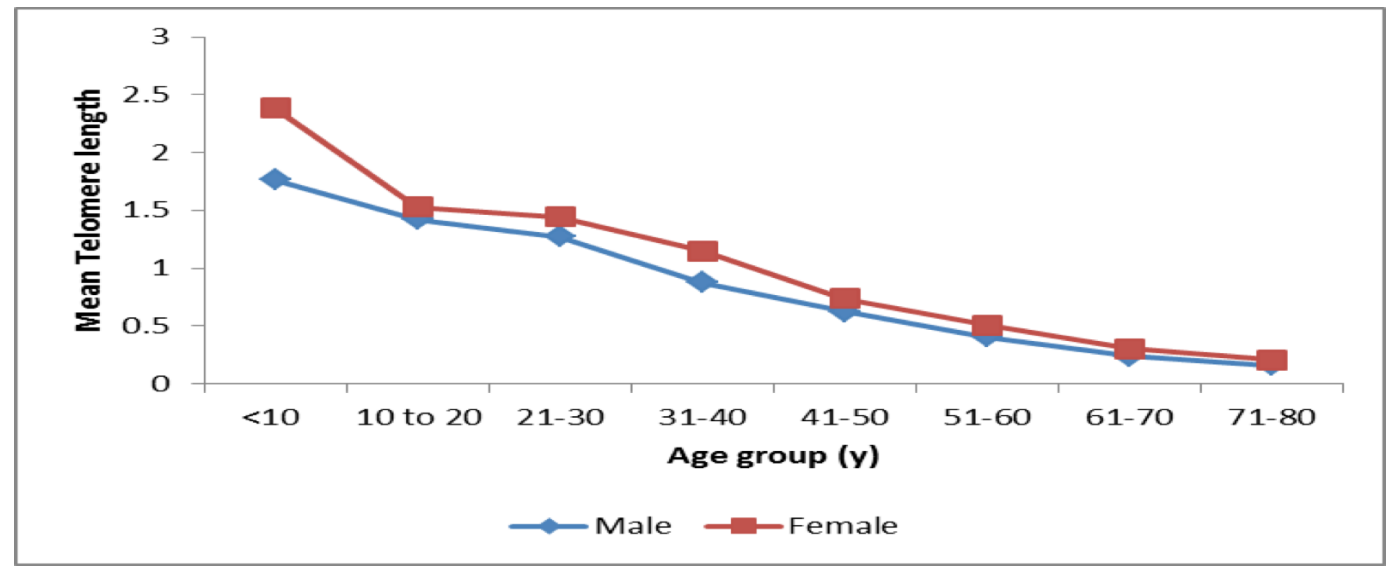

Fig. (4) : Scatter plot showing the relation between mean relative telomere length (TL) and age of individuals among the studied eight sub-groups (decades of life), according to gender distribution.

Table (2) : Regression analysis for prediction of age from relative telomere length with the formula for age prediction:

\begin{tabular}{|l|c|c|c|c|c|c|}
\hline \multicolumn{1}{|c|}{ Variables } & $\begin{array}{c}\text { Equation } \\
\left(\mathbf{Y}=\mathbf{b}_{\mathbf{0}}+\mathbf{b X}\right)\end{array}$ & $\pm \mathbf{S E E}$ & $\mathbf{R}^{\mathbf{2}}$ & $\begin{array}{c}\text { Adjusted } \\
\mathbf{R}^{\mathbf{2}}\end{array}$ & $\begin{array}{c}\mathbf{t}- \\
\text { value }\end{array}$ & P-value \\
\hline Model for total sample & $\mathrm{Y}=66.9-28 \mathrm{X}$ & \pm 10.14 & 0.815 & 0.813 & 36.3 & $<0.001$ \\
\hline Model for males & $\mathrm{Y}=65.3-27.05 \mathrm{X}$ & \pm 10.81 & 0.796 & 0.790 & 24.3 & $<0.001$ \\
\hline Model for females & $\mathrm{Y}=68.8-29.1 \mathrm{X}$ & \pm 9.59 & 0.839 & 0.835 & 27.04 & $<0.001$ \\
\hline
\end{tabular}

$\mathrm{Y}=$ the predicted variable (Age), $\mathrm{b}_{0}=$ constant (intercept of the regression line), $b=$ regression coefficient (Slope of the regression line), $\mathrm{X}=$ Telomere length. SEE, standard error of estimate, $\mathrm{R}^{2}$ : Coefficient of determination, adjusted $R^{2}$ : the adjusted value was used as unadjusted $R^{2}$ usually overestimate the association. 


\section{DISCUSSION}

When there is no a suspect to compare his/her DNA with the DNA extracted from a biological evidence left in a crime scene, it would be useful to predict what the person of interest looks like, e.g. (age, gender, ethnicity, etc.) by analyzing DNA (Hewakapuge et al., 2008).

So far, most common macroscopic methods of age identification are based on examination of dental and skeletal development. However, these methods are often qualitative, and their accuracy is much reduced in adulthood (Cameriere et al., 2007). In addition, these methods cannot be practically applied to samples carried no morphologic information such as bloodstain and parenchyma (Tsuji et al., 2002).

So, estimation of the individual age using techniques of molecular biology, such as those based on telomere length (TL) would be of importance in forensic investigations (Ren et al., 2009).

The fact that telomere shortening occurs leads to the hypothesis that by measuring their length, a correlation could be made to the age of the suspect (Karlsson et al., 2008; Zhu et al., 2011).

The present work clearly illustrated that the relative TL significantly shortened with aging, among all individuals included in the study with a correlation coefficient " $r$ " $=-0.903(p<0.001)$, and also showed a highly significant $(\mathrm{p}<0.001)$ decrease in mean relative TL among the different age sub-groups.

These results were consistent with the previous observations of Guan et al. (2007), Hewakapuge et al. (2008) and Kimura et al. (2008) who confirmed that the length of telomeres decreased with age.

Figura et al. (2009) concluded that telomere shortening occurs as a consequence of proliferation along with each cell division, because of the end-replication problem of DNA-polymerase.

Various studies reported different correlation coefficient " $r$ " values of this significant negative correlation between TL and age; Hewakapuge et al. (2008) in Australia $(\mathrm{r}=-0.185, \mathrm{p}<0.05)$, Zubakov et al. (2010) in Netherlands ( $\mathrm{r}=-0.987, \mathrm{p}<0.01)$, Hoffmann et al. (2009) in Germany ( $\mathrm{r}=$ 0.601, $\mathrm{p}<0.05$ ), and Nordfjall et al. (2005) in Sweden $(\mathrm{r}=-0.233, \mathrm{p}<0.01)$; all used a quantitative real-time PCR method to measure the TL.

Meanwhile, others used the terminal restriction fragments (TRF) length method to measure the TL, as Ren et al. (2009) in China who recorded a correlation coefficient " $r$ " value $=-0.913$ and $p<0.01$, Tsuji 
et al. (2002) and Takasaki et al. (2003) in Japan; $\mathrm{r}=-0.832$ and -0.749 respectively, and $\mathrm{p}<0.01$.

Hewakapuge et al. (2008) explained the differences in the observed " $\mathrm{r}$ " values as a result of differences in ethnicity, sample size, laboratory conditions in each study, and not due to differences in measuring TL in different methods.

Ballantyne (2007) and Haussmann and Mauck (2008) stated that there were many conflicting reports regarding the reliability and reproducibility of TL as a molecular tool for age estimation.

The present study found that estimation of human age based on the relative TL measured by the real-time quantitative PCR may be a useful method for age prediction, especially when there is no morphologic information in the biological sample. Meanwhile it could only give a rough estimation of age or could be assigned to an age interval, as the age prediction value " $\mathrm{R}^{2}$ " was 0.815 , and the estimated standard error of age prediction was still quite high (around \pm 10 years; \pm 10.14 in total sample, \pm 10.81 in males and \pm 9.59 in females) to be used with certainty in forensic investigations.

These results were in accordance with Zubakov et al. (2010) in Netherlands, who confirmed that age estimation based on TL measured by quantitative PCR method was expected to provide a useful investigative tool in forensic practice, the recorded $\mathrm{R}^{2}=0.836$ and the standard error of the estimate \pm 8.9 years.

Meissner and Ritz-Timme (2010) concluded that TL can only be assigned to an age interval, with very limited accuracy, so it may be a complementary method for age estimation in soft tissues.

Ren et al. (2009) confirmed that estimation of human age according to telomere shortening was a novel method, they recorded $R^{2}=0.692$ and a standard error of estimate of \pm 9.832 years. They concluded that this method could only give a rough estimation of age, and it required a largescale anthropological investigation before its application in forensic practice.

Takasaki et al. (2003) showed that TRF length of telomeres from dental pulp DNA is a useful method to estimate age, with $\mathrm{R}^{2}=0.562$ and a standard error of estimate of about \pm 7.52 years.

Also, Tsuji et al. (2002) found that TRF length of telomeres of blood samples is a useful tool for determining the age, with $\mathrm{R}^{2}=0.692$ and a standard error of estimate of only \pm 7.03 years.

In contrast Baird et al. (2005); Hewakapuge et al. (2008) and Karlsson et al. (2008) 
confirmed that age estimation based on telomere shortening measured with realtime PCR is not appropriate for age estimation in forensic practice, as there was a relatively large variation between individuals, e.g. in the study of Karlsson et al. (2008), $\mathrm{R}^{2}=0.3$ with standard error of age prediction estimated to be much higher as \pm 22 years, while in the study of Hewakapuge et al. (2008), $\mathrm{R}^{2}$ value was 0.037 which was significantly low.

In the present work, the correlation coefficient " $r$ ", the regression $\left(R^{2}\right)$ values between TL and age were higher and the estimated standard error of age prediction was much lower than in some previous studies, probably due to the inclusion and exclusion criteria used to eliminate some factors that may affect TL such as inheritance, ethnicity and chronic diseases. The present study still detected some interindividual variations in telomere lengths that must be considered when applying this method of age estimation. For example there were inter-individual variations between individuals of the same age and some of the older individuals had a longer telomere length than younger individuals.

Hewakapuge et al. (2008) in Australia when they analyzed the TL of non-related Caucasians to exclude the effects of ethnicity and inheritance on TL, the correlation coefficient " $r$ " value increased $(r=-0.233$,
$\mathrm{P}<0.05)$, and also age prediction accuracy increased to $5.45 \%$.

Karlsson et al. (2008) stated that factors causing the variability in the TL among individuals may arise from the TL at birth, and many other competing set of positive and negative factors throughout life, such as age, gender, race, disease, lifestyle, cigarette smoking, stress and an upregulation of the immune system (i.e. infection).

Brouilette et al. (2007) and Salpea et al. (2010) confirmed that oxidative stress conditions has been found to accelerate telomere shortening and has been linked to psychological disorders, diabetes, inflammation, and vascular diseases.

Saeed et al. (2012) stated that despite the fact that many pathological diseases have been found to cause telomere shortening, the direct mechanisms for these effects remain unknown.

Telomerase is a reverse transcriptase enzyme that elongates telomeres and compensates for the loss of telomeric DNA during replication (Harley et al., 1990).

Wright et al. (1996) and Ritz-Timme and Collins (2002) stated that telomerase activity in forensically relevant biological samples could potentially impact the viability of TL as a biomarker for age. 
Graakjaer et al. (2006) concluded that newborn TL is mainly determined genetically and the variation of TL among population reflects its genetic variation even in adults.

It should be noted that TL is not applicable for old dried biological samples, as Tsuji et al. (2002) found that dried bloodstains stored for 5 months revealed a mean TL 500 bp shorter than that of freshly drawn blood samples from the same individuals.

The gender must be considered when an individual age is estimated based on telomere shortening; the present study confirmed that there was a gender-specific difference in relative TL; it was significantly $(p<0.001)$ longer in females than males of the corresponding age among all studied individuals. When the studied individuals were classified into eight age groups representing the decades of life, the mean relative TL was significantly $(p<0.05)$ longer in all females than males, except in age groups ( $<10$ years, $31-40$ years and 41-50 years) which was insignificantly $(p>0.05)$ longer in females than males.

Hoffmann et al. (2009) found that women have significantly longer telomeres compared to the male population, and referred that to the expression of the estrogen receptors in the female cells.
Ren et al. (2009) reported that TL was significantly longer in females than in males, specially, in two age groups (5-14 years old and 55-64 years old). However, telomere length did not differ between male and female newborns.

Nordfjall et al. (2005) found that males lost TL rapidly than females; 25 bp per year compared to $16 \mathrm{bp}$ per year loss in women.

Effros et al. (2005) showed that the treatment of T-lymphocytes with estrogen enhances telomerase activity in these cells, and hence prevents telomeres from rapid shortening, as occurred in females.

On the other hand, Guan et al. (2007) concluded that the variation in the telomere attrition rates between males and females beyond age of 50 years cannot be simply explained by estrogen-related effects but by other unknown factor(s). As this tendency was reversed after age of 50 years, as males had a reduced telomereshortening rate after 50, however, cannot be explained by changes in estrogenrelated telomere maintenance.

\section{THE PRESENT STUDY CONCLUD-} ED THAT:

Estimation of human age based on the relative TL measured by real-time quantitative PCR may be a useful method for age prediction, especially when there is no 
morphologic information in the biological sample, although the estimated standard error of age prediction in this study was quite high ( \pm 10 years) to be used with certainty in forensic investigations.

Inter-individual variations in TL and variability among the gender must be also considered when applying this method.

So, this method could only give a rough estimation of age and it may be a complementary method for age estimation in soft tissues.

\section{RECOMMENDATIONS:}

Large scale studies with a big sample size in population are recommended before its application in forensic practice.

Multi-generation studies conducted on shorter-lived animal models such as mice (as these studies may be difficult to conduct in human) may shed light on the mode of inheritance of telomere lengths.

A study exploring the correlation between single chromosome TL and age may better determine the exact strength of the correlation between age and TL and may reduce the individual variations.

It is critical to know which cells and chromosomes are susceptible to telomerase activity and the effect of telomerase activity on TL.

\section{ACKNOWLEDGMENT}

Our deep gratitude and thanks to all members staff in Molecular Biology Unit, Benha Faculty of Medicine, Benha University, for their great help and cooperation. www.fmed.bu.edu.eg

\section{REFERENCES}

Alaeddini, R.; Walsh, S.J. and Abbas, A. (2010): "Forensic implications of genetic analyses from degraded DNA-a review". Foren. Sci. Int. Genetics, 4:148-157.

Alhusseini, N.F.; Ali, A.I.; Abul-Fadl, A.M.A.; et al. (2014): "Gene expression of FADS2 mRNA linked to intelligence in exclusively breast milk fed preterms". Am. J. Biochem. Biotechnol., 10: 267-274.

Baird, D.M.; Britt-Compton, B.; Rowson, J.; et al. (2005): "Telomere instability in the male germline". Hum. Mol. Genet., 15: 45-51.

Ballantyne, J. (2007): "Final report: the determination of the physical characteristics of an individual from biological stains". Nation. Instit. Justice, 1-193.

Boulay, J.L.; Reuter, J.; Ritschard, R.; et al. (1999): "Gene dosage by quantitative real-time PCR". Biotechniques, 27: 228-232. 
Brouilette, S. W.; Moore, J. S.; McMahon, A. D.; et al. (2007): "Telomere length, risk of coronary heart disease, and statin treatment in the West of Scotland primary prevention study: a nested case-control study". Lancet, 369: 107-114.

Cameriere, R.; Ferrante, L.; Belcastro, M.G.; et al. (2007): "Age estimation by pulp/tooth ratio in canines by peri-apical x-rays". J. Foren. Sci., 52: $166-170$.

Cawthon, R. M. (2002): "Telomere measurement by quantitative PCR". Nucleic Acids Res., 30 (10): 1-6.

Dawson, S. B. and Trapp, R. (1994): Basic and clinical biostatistics. In: Biostatistics: A Foundation For Analysis In The Health Sciences, Lange Medical Book, prentice - Hall International Inc, $2^{\text {nd }}$ ed., chapter (4), P.P: 201-205.

Effros, R.B.; Dagarag, M.; Spaulding, C. and Man, J. (2005): "The role of CD8+ $\mathrm{T}$-cell replicative senescence in human aging". Immunol. Rev., 205: 147-157.

Figura, G.V.; Hartmann, D.; Song, Z. and Rudolph, K.L. (2009): "Role of telomere dysfunction in aging and its detection by biomarkers". J. Mol. Med., 87: 1165-1171.

Graakjaer, J.; Der-Sarkissian, H.;
Schmitz, A.; et al. (2006): "Allele-specific relative telomere lengths are inherited". Hum. Genet., 119: 344-350.

Guan, J. Z.; Maeda, T.; Sugano, M.; et al. (2007): "Change in the telomere length distribution with age in the Japanese population". Mol. Cell Biochem., 304: 353-360.

Harley, C.B.; Futcher, A.B. and Greider, C.B. (1990): “Telomeres shorten during ageing of human fibroblasts". Nature, 345:458-460.

Haussmann, M.F. and Mauck, R.A. (2008): "New strategies for telomere-based age estimation". Mol. Ecol. Resour., 8: 264-274.

Hewakapuge, S.; Oorschot, R.A.H.; Lewandowski, $P$. and Baindur-Hudson, S. (2008): "Investigation of telomere lengths measurement by quantitative real-time PCR to predict age". Legal Med., 10: 236-242.

Hoffmann, J.; Erben, Y.; Zeiher, A. M.; et al. (2009): "Telomere lengthheterogeneity among myeloid cells is a predictor for chronological ageing". Experiment. Gerontol. 44: 363-366.

Karlsson, A.O.; Svensson, A.; Marklund, A. and Holmlund, G. (2008): "Estimating human age in forensic samples by 
analysis of telomere repeats". Foren. Sci. Int. Genetics Suppl. Series, 1: 569-571.

Kelly, H.; Bright, J.A.; Buckleton, J.S. and Curran, J.M. (2013): “A comparison of statistical models for the analysis of complex forensic DNA profiles". Sci. Justice, 54(1): 66-70.

Kimura, M.; Hjelmborg, J.V.; Gardner, J.P.; et al. (2008): "Telomere length and mortality: a study of leukocytes in elderly Danish twins". Am. J. Epidemiol., 167: 799-806.

Lynnerup, N.; Kjeldsen, H.; Zweihoff, R.; et al. (2010): "Ascertaining year of birth/age at death in forensic cases: a review of conventional methods and methods allowing for absolute chronology". Foren. Sci. Int., 201:74-78.

Meissner, C. and Ritz-Timme, S. (2010): "Molecular pathology and age estimation". Foren. Sci. Int., 203: 34-43.

Nakagawa, S.; Gemmell, N.J. and Burke, T. (2004): "Measuring vertebrate telomeres: applications and limitations". Mol. Ecol., 13: 2523-2533.

Nordfjall, K.; Larefalk, A.; Lindgren, P.; et al. (2005): "Telomere length and heredity: indications of paternal inheritance". Proc. Natl. Acad. Sci. U.S.A., 102: 16374-16378.
Price, L.H.; Kao, H.; Burgers, D.E.; et al. (2013): "Telomeres and early-life stress: an overview". Biol. Psych., 73:15-23.

Ren, F.; Li, C.; Xi, H.; Wenet al. (2009): "Estimation of human age according to telomere shortening in peripheral blood leukocytes of Tibetan". Am. J. Foren. Med. Pathol., 30: 252-255.

Ritz-Timme, S. and Collins, M. J. (2002): "Racemization of aspartic acid in human proteins". Aging Res. Rev., 1: 43-59.

Saeed, M.; Berlin, R.M. and Cruz, T.D. (2012): "Exploring the utility of genetic markers for predicting biological age". Legal Med., 14: 279-285.

Salpea, K.D.; Talmud, P.J.; Cooper, J.A.; et al. (2010): "Association of telomere length with type 2 diabetes, oxidative stress and UCP2 gene variation". Atherosclerosis, 209: 42-50.

Takasaki, T.; Tsuji, A.; Ikeda, N. and Ohishi, M. (2003): “Age estimation in dental pulp DNA based on human telomere shortening". Int. J. Legal Med., 117: 232-234.

Thomas, P.; Callaghan, N.G.O. and Fenech, M. (2008): "Telomere length in white blood cells, buccal cells and brain tissue and its variation with ageing and 
Alzheimer's disease". Mech. Ageing Develop., 129: 183-190.

Tsuji, A.; Ishiko, A.; Takasaki, T. and Ikeda, N. (2002): "Estimating age of humans based on telomere shortening". Foren. Sci. Int., 126: 197-199.

Wright, W.; Piatyszek, M. Rainey, W.E.; et al. (1996): “Telomerase activity in human germ-line and embryonic tissues and cells". Dev. Genet., 18: 173-179.
Zhu, H.; Wang, X.; Gutin, B.; et at. (2011): "Leukocyte telomere length in healthy caucasian and african-american adolescents: relationships with race, sex, adiposity, adipokines, and physical activity". J. Pediat., 158 (2): 215-220.

Zubakov, D.; Liu, F.; Van Zelm, M. C.; et al. (2010): "Estimating human age from T-cell DNA rearrangements". Current Biology, 20 (22): 970-971. 


\title{
طول التيلو مير كهؤ شر جزيئي للتنبؤ بالعهر البشرى: دراسة بتفاعل البوليميريز الهتسلسل الكمى اللحظى فى عينة عـ الهصريين
} المشتركون فى البحث

\author{
د. عبد الهنعمم جودة مدبولى .نجـلاء فتحسى الحسينـى \\ د. عبيــر أبـو العـزمم \\ من أقسام الطب الشرعى والسموم الأكلينيكية، الكيميا ء الحيوية الطبية*، الميكروبيولوجيا الطبية والمناعة **، \\ كليــة الطب - جامعة بنهـــا
}

حقيقة أن طول التيلومير ينقص مع التقدم فى العمر أدي إلى الفرضية القائلة بوجود علاقة بين طول التيلومير وعمر المشتبه به. وقد أجريت هذه الدراسة لتقييم ما إذا كان طول التيلومير يمكن استخدامه كأداة فحصية للتنبؤ بعمر الإنسان من خلال انشاء معادلة تستند إلى هذه العلاقة بمستوى دقة كافي ليتم تطبيقها في الممارسات الطبية الشرعية. أجريت هذه الدراسة باستخدام تفاعل البوليميريز المتسلسل الكمى اللحظى على •^ حالة من المصريين، تتراوح أعمارهم من 1-19 عاما. . وأكدت نتائج هذه الدراسة وجود علاقة عكسية ذات دلالة إحصائية بين طول

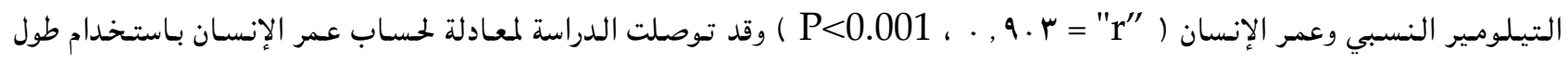
التيلومير النسبي و هى (Y=66.9-28X) بحيث أن (Y) = العمر بالسنوات؛ و X Xول التيلومير النسبي. ومع تحليل الانحدار بين

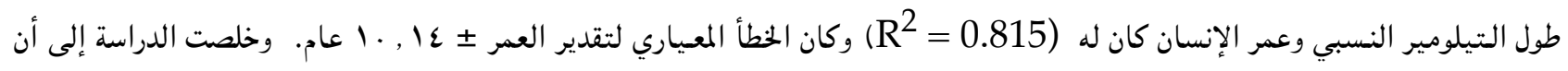
تقدير عمر الإنسان على أساس طول التيلومير النسبي المقاس باستخدام تفاعل البوليميريز المتسلسل الكمى اللحظى قد يكون وسيلة مفيدة للتنبؤ بعمر الإنسان، وخاصة عندما لا يكون هناك معلومات شكلية أو ظاهرية تدل على عمر الإنسان في العينات البيولوجية مثل عينات الدمر أو السائل المنوى رأو الأنسجة الرخوة، ولكن مع وجود ما أثبتته هذة الدراسة من اختلافات بين الأفراد في طول التيلومير روالتباين بين الجنسين، وكذلك ارتفاع الخطأ المعيـاري المقدر للتنبؤ بالعمر في هذه الدراسة الى حد ما (土 . اعام) يصبح من الصعب استخدام هذه الطريقة بمفردها بدقة مناسبة في قضايا الطب الشرعي. ويكن لهذه الطريقة أن تعطي تقدير تقريبي للعمر ، وأنها قد تكون وسيلة مكملة لتقدير العمر من الأنسجة الرخوة مستقبلا". 